\title{
Yaojia-Nenjiang Formation Hydrocarbon Accumulation Characteristics in Songliao Basin, Northeastern China
}

\author{
Chao Wang \\ Daqing Oilfield Exploration and Development Research Institute, China
}

57113728@qq.com

\begin{abstract}
Keywords: Yaojia-Nengjiang Formation $\left(\mathrm{K}_{2} \mathrm{y}, \mathrm{K}_{2} \mathrm{n}\right)$; Sedimentary evolution; Hydrocarbon distribution; Lithological Hydrocarbon Reservoir; Songliao Basin.
\end{abstract}

\begin{abstract}
The reservoir of Late Cretaceous Yaojia-Nengjiang Formation in Songliao Basin was a large-scale delta complex formed in the transgression and regression period, which had the characteristics of sand body in distributary channel, mouth bar and sheet sand. The sand bodies extended to the lacustrine center and wedged into lacustrine mudstone and mature source rock, and formed a good combination of source, reservoir and cap rock. The large-scale delta complexes developed in the major axis direction of the material source of basin were favorable places for centrally developed oil reservoir, which is an important geological condition for mega continental petroliferous basin. Moreover, the gravity flow channel and slump fan, which are important exploration areas, are also favorable for lithological hydrocarbon reservoir.
\end{abstract}

\section{Introduction}

Late Cretaceous $\mathrm{K}_{2} \mathrm{y}$ and $\mathrm{K}_{2} \mathrm{n}$ are integrated transgressive and regressive cycle formation formed in the depression period of Songliao Basin.Putaohua, Saertu and Heidimiao Oil-layers are the main horizons for oilfield exploration and development. Controlling effect of base level cycle on both sequence and sediment and characteristics of hydrocarbon accumulation and distribution corresponding to sedimentary filling pattern is emphasized in the article.

\section{Geological background of Songliao Basin}

Songliao Basin, located in Northeast China, has a NE oriented major axis, it is a Mesozoic and Cenozoic large-scale continental depression basin (Liu, 1993; Yang, 1983; Watson, 1987 ;). Songliao Basin can be divided into six first-order tectonic units, including northern dip-down, central depression, northeast uplift, southeast uplift, southwest uplift and west slope units, and 31 second-order tectonic units. The tectonic evolution of Songliao Basin is divided into three periods, including fault, depression and inversion, corresponding to three sets of formation in faulting, depression and inversion periods respectively. Oil produced in Songliao Basin were mainly from formations formed in depression period.Putaohua and Saertu Oil-layers are the mainly pay zones (Yang, 1985), which counts for $60 \%$ of the total reserve.

\section{Sequence stratigraphy of K2y and K2n}

The forced regression took place when supply of sediments exceeded the increase in capacity of storage during the descending period of base level. The progradation sedimentary sequence is a passive marine regression sequence, which is a special case of marine regression. Because it was heavily influenced by tectonic activity, this special case could be applied to continental lake basin as well (Wu, 2003; Emery, 1996; Posamentier, 1992). $K_{2} n_{2}$ to $K_{2} n_{5}$ in Songliao Basin is a progradation sequence formed during forced regression. $\mathrm{T}_{07}$ seismic reflection axis, corresponding to the maximum flooding surface in lower part of $K_{2} n_{2}$, is a second-order sequence interface. $K_{2} y-K_{2} n$ located on the top of depression formation in Songliao Basin and demonstrates a progression-regression sedimentary cycle (Gao, 1994). It can be divided into 2 second-order 
sequences and 5 third-order sequences. $\mathrm{T}_{03}$ regional tectonic inversive unconformity interface between $\mathrm{K}_{2} \mathrm{n}$ and Sifangtai Formation is the interface of top Sequence II 4. The upper and lower lithology is lacustrine grey fine clastic sandstone and the age of the unconformable contact with upper Sifangtai coarse clastic sandstone is 79Ma year-old. The bottom of Sequence II 3 is $\mathrm{T}_{1}{ }^{1}$ sedimentary unconformable interface, corresponding to a set of mauve mudstone with conformable contact in the central depression unit of basin, and is 88Ma year-old. The sedimentary base level above the interface rose rapidly, developed the $\mathrm{T}_{1-1}$ and $\mathrm{T}_{1}$ second-order flooding surface and formed a large-scale lacustrine-delta deposit with characteristics of regression sequence. $T_{07}$ maximum flooding surface at the bottom corresponds to a set of $10 \mathrm{~m}$ thick oil shale Seismic reflection characteristics of $\mathrm{T}_{07}$ is, consistent and strong which is the important for stratigraphic correlation in the whole basin. The sedimentary base level above the interface descended rapidly and formed lacustrine and high-angle procreation delta deposit.

\section{Reservoir distribution characteristics}

Reservoir distribution characteristics controlled by water progressive sequence. Putaohua and Saertu Oil-layers are oil-bearing combination formed in transgressionperiod. Oil formed at lower layers and stored at layers above. These two layers are where reservoirs concentrated in Songliao Basin. Oil reserve of these two layers counts for $60 \%$ of the total reserve of the basin. Putaohua Oil-layer mainly distributed in delta sandbody of the northern water system and in delta front facies belt of western water system. Saertu Oil-layer is a large-scale structural reservoir in Daqing Placanticline's northern water system. Gravity caused obvious separation of oil, gas and water Because of the separation, a gas cap formed in the higher part of the structure (Figure1), an secondary reservoir formed from long distance oil migration in certain part of the western slope and lithologic reservoirs spreat sparsely in delta front facies belt of western minor axis. During transgression period of $\mathrm{K}_{2} \mathrm{n}_{1}$, massive gravity flow channel and underwater fan formed in delta front of the northern water system. Commercial oil-gas flow was found in few exploration wells in these sandbodies. These sandbodies are good lithologic reservoir and provides possibilities for finding reservoir within lacustrine mudstone in Songliao Basin.

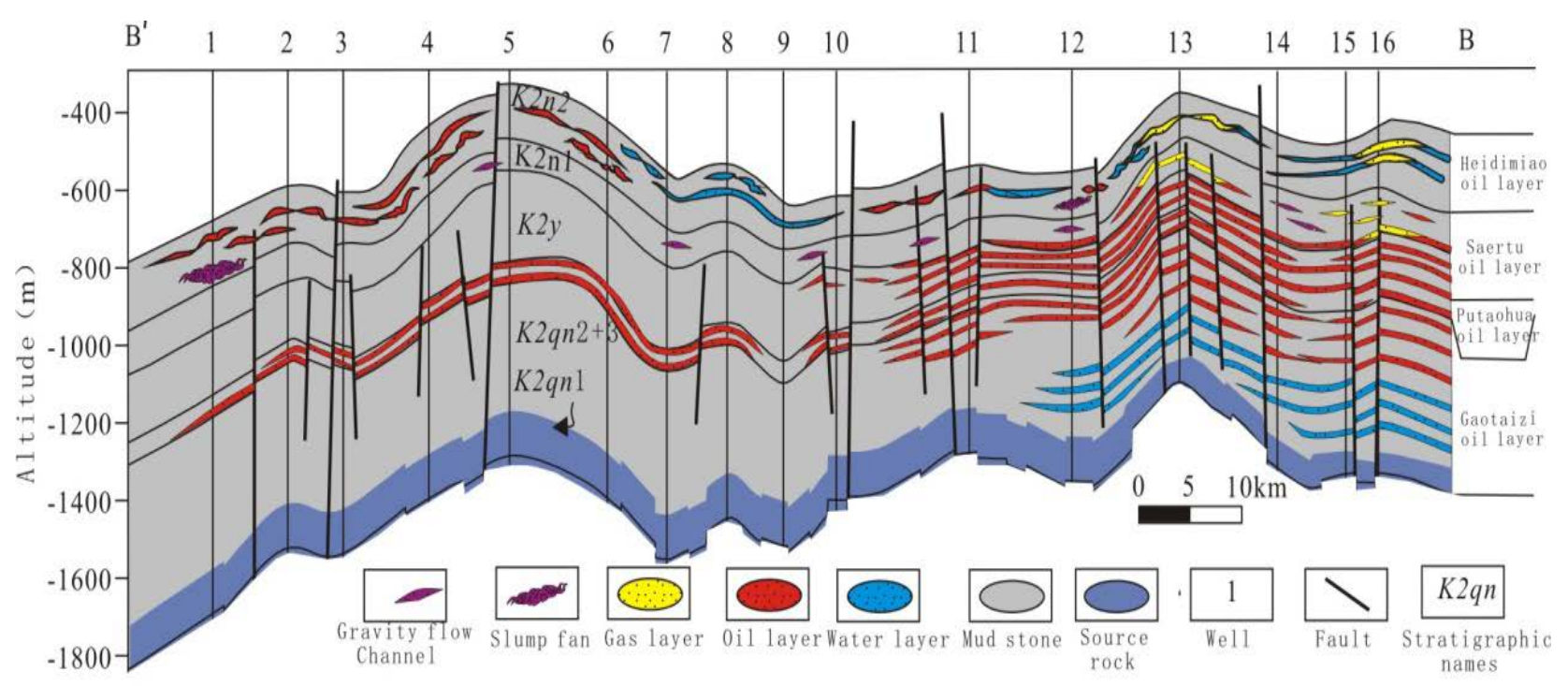

Fig.1 Cross-section of Heidimiao oil layers, Sartu oil layers, and Putaohua oil layers of Songliao Basin

Reservoir distribution characteristics controlled by forced water regressive sequence. During $\mathrm{K}_{2} \mathrm{n}_{1-2}$ lake flooding period, in Qijia-Gulong, mudstone maturity was greater than $0.7 \%$ in Qijia-Gulong's sag. In southern Daan Area, mudstone maturity reached 1.2\%, which entered the peak hydrocarbon generation stage. Therefore, the reservoir of Heidimiao Oil-layer mainly distributed in 
southern Daqing Placantieline and southern Qijian-Gulong Depression. Vertically, the reservoir centrallized in the delta front mouth bar facies belt of $K_{2} n_{3}$ in the form of lens-like lithologic reservoir. Massive slump fans formed in high-angle progradation delta front of $K_{2} n_{2}$, which were in lacustrine mudstone, and formed a lens-like lithologic trap (Zhao, 2011). At present, 7 slump fans were found in Maoxing Area of southern Daqing Placantieline. Commercial oil and gas flow was found in some drilled fan. Thus, slump fan developed in shore-shallow lake is a favorable reservoir for development.

Generally, reservoirs of Putaohua, Saertu, and Heidimiao Oil-layer mainly distributed in area with highly mature source rock in central depression unit, presenting lithologic characteristics in large-scale delta front facies belt, such as Qijia-Gulong Sag. Structural reservoir centralized in facies belt of delta plain with thick sandbody and desirable physical property and connectivity. To be mentioned, the structural reservoir in central and northern part of Songliao Basin presents the characteristics of large-scale anticline structural reservoir.

In the past 20 years, lots of study were done on deep-sea gravity flow (Shanmugam, 2000; Bauman, 2000; Weimer, 1991). The findings of large-scale marine channel provide relatively complete geological data for study on submarine turbidite fan. Achievements were also made in study on turbidite fan and turbidite channel of continental turbidite system. Also, a large-scale gravity flow channel and slump fan were found in a large continental depression in Songliao basin for the first time, which has significant meaning for further understanding on sedimentary process of transgression and regression and provides ideal exploration targets in reservoir with lacustrine mudstone.

\section{Conclusions}

Horizontally, controlled by the distribution of mature source rocks, reservoirs mainly developed in the central depression unit. Because of the gravity flow sedimentary sandbody, which developed during water transgression and regression, the lacustrine mudstone region became an important exploration region in Songliao Basin.

All large-scale reservoirs developed during the rise cycle of base level and were controlled by the widely distributed oil shale and very thick deep-lacustrine mudstone deposited during maximum lake flooding period in the basin. Cap rock conditions were favorable. Due to the limitation of mature source rock and cap rock distribution, it was hard to form a large-scale continuously distributed reservoir in fall cycle.

\section{References}

[1]Liu Li. 1993,Basement structure of Mesozoic and Cenozoic basin in Manzhouli-Suifenghe Geoscience Transect and its Sedimentary Structure Evolution [M]. Beijing: Geological Press. (In Chinese)

[2]Yang Jiliang.1983,Geologic Structure in Faulted Basin of Songliao Basin and its Hydrocarbon [M].Beijing: Science Press, (In Chinese)

[3]M. P. Watson, A. B. Hayward, D. N. Parkinson etal.. 1987,Plate tectonic history, basindevelopment and petroleum source rock deposition onshore China [J]. Marine and Petroleum Geology, 1987, Vol 4, p. 205-225.

[4]Yang Wanli, Gao Ruiqi, 1985,Continental Hydrocarbon Transportation and Gathering in Songliao Basin [M]. Haerbin: Heilongjiang Science and Technology Press. (In Chinese)

[5]Wu Yinye, Gu Jiayu, Cedric G. etc. 2003,Sedimentary Pattern of Forced Marine Regression System in western Tarim Basin [J]. Acta Petrolei Sinica, 24(4): 21-25. (In Chinese)

[6]Emery D,Myers K J.1996,Sequence Stratigraphy [M] .Blackwell Science:p. 11-265.

[7]Posamentier H W.1992,Forced reressions in a sequence stratgraphic framework: concepts, examples, and explora -tion significance [J].AAPG Bulletin, 76(11):p. 259-267. 
[8]Gao Ruiqi, Zhang Ying. 1994,Cretaceous Preliferous Formation in Songliao Basin [M].Beijing: Petroleum Industry Press. (In Chinese)

[9]Wenzhi Zhao, Caineng Zou, Yingliu Chi,Hongliu Zeng,2011,Sequence stratigraphy, seismic sedimentology, and lithostratigraphic plays: Upper Cretaceous, Sifangtuozi area, southwest Songliao Basin, China.AAPG Bulletin, 95(2), p. 241-265.

[10]G.Shanmugam, 2000,50 years of the turbidite paradigm (1950s-1990s): deep-water processes and facies models-a critical perspective[J]. Marine and Petroleum Geology, 17: p. 285-342.

[11]Bouma A H, Stone C G.2000,Fine Grained Turbidite Systems [J].AAPG,68:p. 1-19.

[12]Weimer P, LinkM H.1991,Seismic facies and sedimentary processes of submarine fans and turbidite systems. New York[J]. Springer, p. 447. 